$$
\text { Vol. } 41 \text { June, } 1972 \quad \text { No. } 2
$$

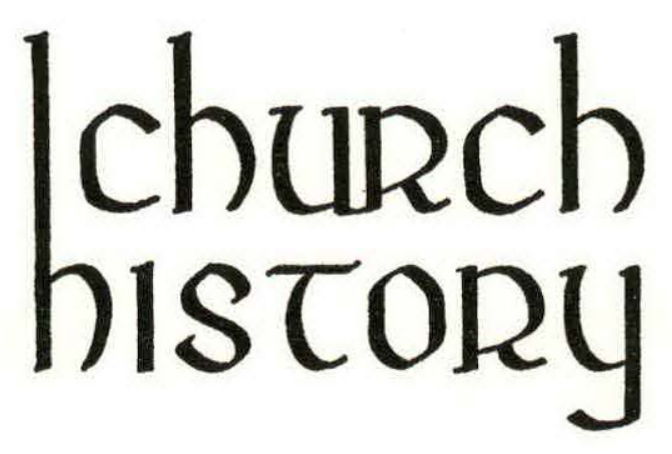

*2 2 f

Published quarterly by

THE AMERICAN SOCIETY OF CHURCH HISTORY

(C) 1972, The American Society of Church History 


\title{
The Southern Aid Society and the Slavery Controversy
}

\author{
VICTOR B. HOWARD
}

During the 1830 s American society was swept by a reform movement that had as its goal the improvement and uplift of humanity and human institutions in all facets of personal and associated conduct. The antislavery cause was one of the most dynamic areas of reform, and by the 1840 s the movement against human bondage became almost entirely a campaign of the northern advocates against the peculiar institution of the South. One of the basic sources of this antislavery sentiment was religious in its orientation, and the crusade against slavery secured its enduring strength from the revivalism of the Presbyterian, Congregational and Baptist churches, from the perfectionism which reinforced it among the Methodist and independent Congregationalists, and from the radicalism of the Unitarians and Quakers. ${ }^{1}$ After the Mexican War, the questions revolving around the sectional controversy became the all-absorbing preoccupation of a concerned nation, but while the slavery controversy was only one of the questions involved in the political arena, the morality of slavery was the total issue within religious circles and the churches.

The northern churches were in accord in their view of the institution of slavery as a positive hindrance to the expansion of the gospel, and they looked upon slavery as an evil in the abstract; but there was disagreement within the churches as to how the problem should be met. Many who became committed to organized abolition felt the church should forthwith separate itself from slavery by breaking off communion and fellowship with all churches which admitted slaveholders. The slaveholder should be condemned, denounced, excommunicated and damned until he repented and cleansed himself from the $\sin$ of slavery. The more conservative viewed the institution as anathema in the social structure, with deep historical roots, and the slaveholder as a victim to whom sympathy and pity were due. The slaveholder should not be banished and left with his problem, but should be guided and helped until a solution was found to the grave moral contradiction in the social structure. The conservatives rejected the withdrawal of fellowship as a desertion of the slave as well as the slaveholder, leaving them to the evils of the system. They held that the only solution was to continue bringing the gospel to bear upon slavery until the influence of Christianity would in time work its way on the institution. ${ }^{2}$

1. Gilbert Barnes, The Anti-Slavery Impulse, 18s0-1844 (New York: D. Appleton-Century, 1933), 3-37; John R. Bodo, The Protestant Clergy and Publio Issues, 1818-1848 (Princeton, New Jersey: Princeton University Press, 1954), 112-114; Charles Cole, The Social Ideas of the Northern Evangelists, 1826-1860 (New York: Columbia University Press, 1954), Chapter 7; Timothy L. Smith, Revivalism and Social Reform (Nashville, Tennessee: Abingdon Press, 1957), Chapters 12 and 13.

2. For the developments within the various denominations see Thomas E. Drake, Quakers and Slavery in America (New Haven: Yale University Press, 1950), 133-166; Donald G. Mathews, Slavery and Methodism: A Chapter in American Morality, 1780-1845 (Princeton: Princeton University Press, 1965), 148-176; Victor B. Howard, "The AntiSlavery Movement in the Presbyterian Church, 1835-1861', (Unpublished Ph.D. dissertation, Ohio State University, 1961); Robert C. Senior, "New England Congregationalists and the Anti-Slavery Movement, 1830-1860', (Unpublished Ph.D. dissertation, Yale University, 1954); Robert O. Fife, "Alexander Campbell and the Christian Church

Mr. Howard is professor of history in the Morehead State University, Kentucky. 
ment. $^{30}$ Then Pizzardo agreed, and with that the Vatican ceased its attempts to elicit new assurances from the Government on the maintenance of the status quo among the Christian communities in Palestine.

If London's exchange with the Holy See over Dr. Lang's visit to Jerusalem ended on a less than satisfactory note, George Ogilvie-Forbes was at least partly responsible. Mr. Ogilvie-Forbes was aware that the Foreign Office was unhappy over his earlier failure to act with more firmness when the Vatican first referred to the archbishop's proposed voyage, and it was probably his concern over winning the approval of his superiors that prompted his personal letter of May 4 to George W. Rendel of the Foreign Office. In it he enclosed the Pro-Memoria which he had told Monsignor Pizzardo he would keep for his own information only. It read in part:

.. . Now it has been reported from there [Jerusalem] to the Holy See that inasmuch as there took place in the Choir of The Greeks a religious ceremony with hymns and an appropriate address, the Archbishop [of Canterbury] wearing liturgical vestments, the entry into the Holy Sepulchre could be called solemn or not, according to the various points of view, and therefore it would be an open question whether there has been a violation of the status quo.

The document went on to acknowledge the statement made by the Anglican authorities in Jerusalem and declared that the Vatican Secretariate of State appreciated that there was no intention [my italics] to prejudice the status quo in any manner. ${ }^{31}$

In his letters to Rendel, Mr. Ogilvie-Forbes described the document as a "climb down," seeing the references to the vestments and other details of the Greek ceremony as an attempt at face saving. Ogilvie-Forbes wrote, "I don't think we will hear anything more about the affair and I am pretty sure the Vatican were put up to it . . . by people wanting to make mischief in Great Britain." 32 While he never identified them, Ogilvie-Forbes had previously concluded that Roman Catholic elements in Great Britain and in Palestine had prodded the Vatican into raising objections over Dr. Lang's visit to the Holy Land. At the Foreign Office, however, the prevailing view was that the greatest mischief had resulted from Mr. Ogilvie-Forbes' unskillful handling of the offensive protests by the Holy See..$^{33}$

Whatever the influences were that helped formulate Vatican policy, it is manifestly clear that neither the Greek Orthodox nor the Anglican churches were seeking to enhance their respective interests in Palestine at the expense of the Roman Church. Unwarranted protests of this kind by the Holy See could only render a disservice to the Roman Catholic Church throughout the British Empire, while also prejudicing any effort designed to seek Christian unity. For its part, the British Government need not have disclaimed any official interest in the archbishop's activities when it could scarcely have hoped to dissociate itself totally from them. But responsible officials in London were prudent enough not to allow the altercation to be used by Rome's critics as a pretext for terminating diplomatic relations. Despite occasional difficulties, the British Government has found its Legation to the Holy See to be sufficiently useful to maintain the post to the present day.

30. George Ogilvie-Forbes, British Legation to the Holy See, Rome, to Arthur Henderson, Foreign Office, London. Dispatch No. 94, 4 May 1931, F.O. 371/15332.

31. George Ogilvie-Forbes, British Legation to the Holy See, Rome, to George W. Rendel, Foreign Office, London. Letter, 4 May 1931, F.O. 371/15332.

32. Ibid.

33. George W. Rendel, Foreign Office, London. Minute, 15 May 1931, F.O. 371/15332. 
Many in the North who favored a strong rebuke of the southern churches were driven to this position by a deep-seated feeling that they were personally involved in the guilt of slavery by maintaining membership in a church that contained members who sustained the institution of servitude. To the professed abolitionist, the act of fellowshipping, of joining in communion with a slaveholder, was personal involvement that justified and implied approval of slavery. Since the South was a missionary field for the masses of the northern antislavery religious leaders, the point of personal involvement came with varying degrees of financial support or aid in sustaining churches and religious institutions that tolerated slavery. In the 1840 s many missionary associations began to draw the line against supporting and sustaining missionaries who owned slaves. It was this issue that divided the Baptists in $1845^{3}$

In the same decade the American Home Missionary Society (AHMS), agent of the New School Presbyterian Church and the Congregational associations, quietly established a policy of employing no agents or missionaries who owned slaves. ${ }^{4}$ Since the AHMS had been condemned as an abolitionist organization by southerners and conservative Presbyterians, and also charged with being a pro-slavery organization by abolitionists, the executive committee of the Society quickly moved to free itself of any identification with either group and to set itself upon the safe and neutral seat of a middle-of-the-road organization devoted only to the single-minded benevolence of aiding needy and destitute churches and congregations. In 1841 the roster of officers contained eight directors and vice presidents from the South. In 1842 the number dropped to six southerners, three more were dropped in 1845 , and in 1846 there were only two, both of whom had moved to the South in answer to a call to take up religious and educational works in the church. One of these returned to the North in 1847, and the other was killed in a train wreck in 1855 . At the same time the Society freed itself of all officers who were officially connected with the American Anti-Slavery Society. ${ }^{5}$

This neutral position, however, did not satisfy most antislavery Presbyterians and Congregationalists. Many Congregationalists withdrew from their orthodox associations and presbyteries and became Independent Congregationalists. ${ }^{6} \mathrm{~A}$

in the Slavery Controversy"' (Unpublished $\mathrm{Ph} . \mathrm{D}$. dissertation, University of Indiana, 1960); Mary B. Putnam, The Baptists and Slavery, 1840-1845 (Ann Arbor, Michigan: George Wahr, 1913).

3. Putnam, op. cit., 21 ff; W. D. Weatherford, American Churches and the Negro (Boston: The Christopher Publishing House, 1957), 130-132; David M. Reimers, White Protestantism and the Negro (New York: Oxford University Press, 1965), 7.

4. A. C. Dickerson to Milton Badger, Bowling Green, Kentucky, November 20, 1844; Milton Badger to A. C. Dickerson, January 2, 1845, No. 991, Letter Book, 1844-1845, Volume R; Samuel Reeve to Milton Badger, Richmond, Virginia, June 10, 1845; Milton Badger to Jacob Mitchell, June 27, 1845, No. 228; Milton Badger to Samuel Reeve, July 15, 1845, No. 318, Letter Book, 1845-1846, Volume S.; American Home Missionary Society Correspondence (Manuscript: Dillard University). Hereafter: AHMS Correspondence.

5. American Home Missionary Society Annual Reports (1841), 4-5; (1842), 4-5; (1845), 4-5; (1846), 4-5 (New York: Clayton and Van Norden). The two northerners who represented the South in 1846 were Artemas Bullard (Missouri) and Eliphalet W. Gilbert (Delaware). Two southerners, Frederick A. Ross and Benjamin M. Palmer, were slaveholders. The abolitionists, Gerrit Smith and Arthur Tappan, were on the board of directors in the early 1840 s.

6. Records of the Presbytery of Grand River, Ohio, (1836-1849), II, 20, 46, 273, 278 279, 280, 282, 290 (Manuscript: Western Reserve Historical Society); Charles F. Goss, Cincinnati: The Queen City, 1788-1912, 4 Vols. (Cincinnati: S. J. Clark, 1912), I, 485: Flaval Bascon to Secretary, Chicago, February 15, 1847, AHMS Correspondence. Records of the Presbytery of Chicago (1847-1870), (Manuscript: MeGraw Library, MeCormick Theological Seminary), 49-50, 72-76. Presbytery Reporter, II, No. 1 (May, 
group of Presbyterians, mainly in the Northwest, withdrew from the New School General Assembly and set up the Free Presbyterian Synod. ${ }^{7}$ In 1846 , under the guidance of the officers, some of whom also served as officials of the American and Foreign Anti-Slavery Society, these antislavery Congregationalists and Presbyterians set up their own missionary organization under the name of the American Missionary Association (AMA). The AMA persistently remained the effective gadfly of the AHMS until the Civil War settled the controversy over slavery. ${ }^{8}$

The adoption of the Compromise of 1850, which included a new Fugitive Slave Law, created a moral crisis in the church. The religious associations were pushed by their more vocal and determined antislavery members into a stronger position against slavery in the church. While Congress debated the sectional questions, the New School Presbyterian General Assembly ruled that slaveholding under any other circumstances except in those cases in which it was "unavoidable" was cause for discipline of a member under the same procedures as punishment for any other $\sin .^{9}$

The Congregationalists were even more agitated by the new political developments. In the autumn of 1851 , the antislavery Congregationalists of the Northwest made a determined effort to secure a general convention of all Congregational associations to commit the denomination to a common position on aid to slaveholding churches through the channels of the AHMS.10 Since all of the slaveholding churches which were aided belonged to judicatories of the Presbyterian Church, sectarianism reinforced the antislaveryism of the Congregationalists. A committee was selected by the New York Congregational Association to issue a call for a convention to meet in Albany in October, 1852, to discuss the relations of the AHMS to slaveholding churches. ${ }^{11}$

The Albany Convention calmed the tempest brewing in the West by urging the AHMS to aid only missionaries who so preached the gospel that it had its "full effect in bringing to pass the speedy abolition of the stupendous wrong." 12 Spurred on by the antislavery Congregationalists of the Northwest and the growing influence of "free" missions connected with the AMA, the AHMS restated its policy in an article in the Society's journal, the Home Missionary, for March, 1853. The new policy corresponded with one set forth by the Congrega-

1951), 44-46; Edwin D. Seward to Milton Badger, Beaver Dam, Wiseonsin, June 7, 1847; Alexander Montgomery to Badger, July 3, 1847; Badger to E. D. Seward, July 12, 1847, No. 467, Letter Book, 1847-1848, Volume U; Stephen Peet to Milton Badger, July 5, 1847, AHMS Correspondence. Watchman of the Valley, June 3, 1847.

7. Watchman of the Valley, August 5, October 28, 1847. See Howard, op. cit., 119.

8. Proceedings of the Second Convention For Bible Missions, Held in Albany, September 2 and 3, 1846 (New York: J. H. Tabitt, 1846), 4, 13; Annual Report, American Missionary Association, (1848), 6. "Constitution,"' No. 78519, 78522, American Missionary Association Correspondence (Manuscript Dillard University). Hereafter eited as AMA Correspondence. History of the American Missionary Association (New York: S. W. Green, 1874), 3-4; Lewis Tappan, The Life of Arthur Tappan (New York: Hard and Houghton, 1870), 317-321. See Clifton Johnson, "The Ameriean Missionary Association, 1846-1861: A Study of Christian Abolition" (Unpublished Ph.D. dissertation, University of North Carolina, 1958).

9. Minutes of the General Assembly (New Sehool Presbyterian Church), 1850, 326.

10. S. D. Helm to J. C. Holbrook, Cottonville, Illinois, Mareh 6, 1851; Albert Hale to Milton Badger, Springfield, Illinois, March 13, 1851, AHMS Correspondence; Jonathan Blanchard to J. P. Williston, Brooklyn, New York, September 6, 1851, Samuel Williston Correspondence (Typeseript: Williston Academy, Easthampton, Massachusetts).

11. Prairie Herald (Chicago), March 2, 1852.

12. New York Observer, Oetober 14, 1852; Independent (New York), October 14, 1852; Congregational Year Book, (1852), 344. 
tionalists in 1852, and the Society insisted that it stood on the same ground as that occupied by the General Assembly of the Presbyterian Church in 1850.13 The executive secretaries of the Society began to collect information from missionaries on the status of slavery in the southern churches, and this action took on a more sinister aspect in May, 1853, when the New School General Assembly requested the southern presbyteries to supply information to the next Assembly concerning the extent of slavery in the church. The basic question that the AHMS posed for the missionaries was: Can the whole gospel be preached in your church? This question had been the point at issue in frequent debates before the missionary conventions in the Northwest as well as the subject of the resolution of the Albany Convention. ${ }^{14}$

The movement in the Presbyterian Church and the AHMS quietly to bring an end to the aid given slaveholding churches met with firm resistance among the conservatives in the North and open rebellion on the part of the southern churches. On July 4, 1853, a convention of southern New School Presbyterians met at Murfreesboro, Tennessee, to consider the General Assembly measures and the relations of the southern presbyteries to the national judicatory. The convention advised the southern churches to reject the request for information and called on the conservatives in the North and West to unite with the South in order to preserve the integrity of the church. ${ }^{15}$ The convention recommended that the southern synods set up a missions board, with a corresponding secretary and an agent, which would have the flexibility that would permit the acceptance of aid from the AHMS, the General Assembly's church-extension committee, or any other agency which met the needs of the southern church. ${ }^{16}$

In discussing the Murfreesboro Convention, the New York Journal of Commerce surmised that one of the purposes of the convention might be to consider the policy of the Home Missionary Society in refusing to aid missionaries in the South who held slaves. ${ }^{17}$ Early in July, 1853, the Journal of Commerce suggested that a "Southern Aid Society" was needed to supply aid for churches in the South that could not secure help from the old domestic board. A northern correspondent agreed with the suggestion of the Journal and concurred with the editor's charge that the refusal to aid missionaries who owned slaves was unreasonable. The correspondent felt that there had been enough abuse of the South and everything southern, perpetrated by men who found it easier to abuse slaveholders than to lift a finger to remove slavery by well-directed Christianity in the South. He did not agree with some of his northern colleagues that the gospel could not be preached in the South without mixing it with abolitionism and insisted that the application of the scripture was the only way that slavery could be peacefully removed. "At all events, those who believe this to be the true way, the best way, to free our country of this evil, ought to be allowed to follow what appears to them to be the path of duty," he urged. A southern minister who had lived in the region for forty years explained that his presbytery had been so crippled and cramped by the rule of the AHMS that the members had

13. Home Missionary, XXV, No. 11 (March, 1853), 269.

14. Milton Badger to David Smith, January 25, 1853, No. 2130, Letter Book, 1852-1853, Volume II, AHMS Correspondence. Howard, op. cit., 234. Minutes, General Assembly, 1853, (New School), 333. Prairie Herald, July 1, 1851.

15. New York Observer, July 28, 1853. Christian Observer, July 5, 1853.

16. Journal of Commerce, July 26, 1853. New York Observer, July 28, 1853.

17. Cited by the New York Evangelist, July 14, 1853. 
decided to do what they could on their own and let the rest go undone. ${ }^{18}$

In late July, a group of conservative laymen and clergymen met in New York City and proposed that a society be set up to assist churches in the South which could not secure aid from the American Home Missionary Society. One of those present pledged a gift of one thousand dollars if such an organization were created. Plans were made for a convention to meet in New York in September to organize the new society. The Christian Observer, voice of the conservative Presbyterians in Philadelphia, approved of the proposal and expressed hope that the plan would materialize and that the organization would commence operations at an early date. ${ }^{19}$

For the next month there followed an extended discussion of the pros and cons of the merits and needs of the proposed society. A correspondent to the Journal of Commerce hailed with the delight the proposal for the new society which would rise superior to the narrow prejudice and miserable fanaticism of the day. The AHMS had been and was becoming, if possible, more inoperative and inefficient in the South. He cited a case in Virginia in which the executive committee dismissed a missonary who married an heiress of three slaves. ${ }^{20}$ That the case cited was not an isolated incident seemed to be verified by the Home Missionary article of March, 1853. The editor revealed that when a missionary became, either voluntarily or involuntarily, the owner of a human being, he was "dropped from the list of its agents." As recently as January, 1853, the Society had separated a Virginia missionary from its service when he came into possession of slaves by marriage. ${ }^{21}$

A Presbyterian clergyman from Mississippi maintained that the position announced by the Albany Convention was the real position of the Society. ${ }^{22}$ Apparently in answer to the New York Evangelist's claim that the cause of the scarcity of missionaries in the South was not due to slavery but to the lack of personnel, the Mississippi clergyman denied that the shortage was from a lack of "adequate donations" but insisted it was the result of "abolitionism." 23 A minister from Virginia wrote the editor of the Journal of Commerce that a Southern Aid Society was badly needed in the South because the people were so widely scattered as a result of the peculiar circumstances of plantation life. The correspondent stated that without aid from other regions the ministers were compelled to augment their scanty means from the farm and the schoolroom, and much time and strength were lost to the proper work of their office. "May the noble conception of a Southern Aid Society soon ripen into a glorious reality," concluded the writer. ${ }^{24}$ The editor of the Journal of Commerce copied the report of the home missions activities of the Union (Tennessee) Presbytery from another paper and pointed out that one church which had promised the missionary fifty-six dollars paid him fifty cents. Other missionaries in the Presbytery fared little better. The editor stated that his reason for copying the article was

18. Journal of Commerce, July 21, 1853.

19. Christian Observer, July 23, 1853.

20. Journal of Commerce, August 11, 1853.

21. Home Missionary, XXV, No. 11 (March, 1853), 266. Robert Gray to Milton Badger, Rocky Mount, Virginia, July 5, 1852; C. A. Marvin to Gray, July 22, 1852, No. 660, Letter Book, 1852-1853, Volume I; Gray to Badger, October 9, 1852; Gray to Badger, January 3, 1853, AHMS Correspondence.

22. Journal of Commerce, August 20, 1853.

23. New York Evangelist, July 14, 1853. Journal of Commerce, August 20, 1853.

24. Journal of Commerce, August 24, 1853. 
because he wanted to keep it before the churches that they were not doing their duty. ${ }^{25}$

The convention to organize the Southern Aid Society was held in New York on September 28 and 29,1853. The meeting agreed that it was expedient and necessary to establish a society for the diffusion of gospel truth in the southern states. A committee was selected to draw up an address at an adjourned meeting in October ${ }^{26}$ The address of the convention stated that the Southern Aid Society was organized to take over where the AHMS "paused or faltered." The new society was established because the course which the Home Missionary Society marked out for itself did not permit it to perform the work of the Southern Aid Society, since the old society was restricted by its rules against aiding ministers or missionaries who under any circumstances were slaveholders. ${ }^{27}$ The AHMS could not do the work that the Southern Aid Society had been established to render because the impression was generally held in the South that the AHMS was closely allied with abolitionism. ${ }^{28}$ "Our object is not to enter at all into the absorbing question of slavery and antislavery. We intend neither to assail slavery or defend it. ... We do not propose to enter into any conflict with other missionary organizations," declared the address. ${ }^{29}$ But the promoters of the Southern Aid Society promised a new approach in the way they would deal with the South. "Reproach, calumny, and all sorts of injustice have been tried upon the South for a quarter of a century, without any good results; the Southern Aid Society will try the opposite policy of kindness, sympathy, and co-operation in every good word and work," they promised. ${ }^{30}$ The executive committee was to be composed of at least one representative each from the following denominations: Dutch Reformed, New School Presbyterian, Old School Presbyterian and Congregationalist.

The new society was eagerly welcomed by the conservative religious press, but the more liberal sheets expressed reservations. "It affords us pleasure" to state that the Southern Aid Society was organized, declared the editor of the Christian Observer. ${ }^{31}$ The New York Evangelist did not view the new organization with so much gratification. Whereas the AHMS prefers to aid ministers and churches not connected with slavery, it was noted, this new society would given its preference, if not exclusive support, to ministers and churches holding slaves. "The prime qualification for its favor with be slaveholding, and its influence, so far as it goes, will be to multiply the number of ministers and churches holding that relation," the editor predicted. ${ }^{32}$ In answer, the Christian Observer complained: "We regret that Christian men . . . should so grossly misrepresent a Society formed ... to preach the gospel . . . as did the apostles, without mingling with it the principles and prejudices of any political party." "I "I cordially endorse the effort," added Amasa Converse, the editor, in a letter to Joseph Stiles, the secretary of the Southern Aid Society. "We owe it to the North and

25. Ibid., September 28, 1853, eiting Congregational Journal (Concord, New Hampshire), and Presbyterian Witness (Knoxville, Tennessee).

26. Journal of Commerce, October 1, 1853.

27. Southern Aid Society: Its Constitution and Address to the Christian Public (New York: D. Fanshaw, 1854), 8-9.

28. Journal of Commerce, November 1, 1853. New York Observer, November 10, 1853.

29. Journal of Commerce, November 1, 1853.

30. Southern Aid Society: Its Constitution and Address, op. cit., 12.

31. Christian Observer, October 8, 1853.

32. Cited by Christian Observer, October 29, 1853.

33. Ibid. 
South and to the Saviour," he continued, "to do something in this work which has been so sadly overlooked." 34 The Presbyterian Herald of Louisville also looked on the Southern Aid Society with favor. "If the gospel is the panacea for all the evils of society ... it surely ought to be sent where those evils are the greatest, if the object be to cure them. It cannot cure them without being brought into contact with them," explained the editor. ${ }^{35}$ Henry Cowles, editor of the Oberlin Evangelist, organ of the independent Congregationalists, said he bid the Southern Aid Society God-speed if they preached the whole gospel to the South. But if they aimed especially, not to say chiefly, to assure their southern brethren that they would stand in full repute as unblemished Christians, despite their holding men as property, "then we say-Let Our Hands be Off!" he added. ${ }^{36}$ The New York Tribune had no doubts as to where the Society stood. The organization was formed by men who were most hostile to the abolition of slavery, claimed the editor. ${ }^{37}$

The Southern Aid Society was well received in the South. At the time it was organized, the Presbyterian Witness of Knoxville, Tennessee, predicted that it would receive cordial cooperation in the region. ${ }^{38}$ No fewer than eighteen southern clergymen, almost all New School Presbyterians, attended the organizational meeting. ${ }^{39}$ Since the division of the Old and New School Presbyterian churches in 1836, no aid had been granted to new churches in the lower tier of southern states. When an attempt was made to secure aid for churches in Alabama in 1847, the American Home Missionary Society rejected the request due to the ties of the ministers to slavery. ${ }^{40}$ In 1851 , the Synod of Mississippi set up its own missionary society as a result of the failure of the AHMS to grant aid, and because of the unwillingness of the churches to receive aid through the national society under its recognized terms. In 1853, the Domestic Missionary Society of Virginia took its mature form. ${ }^{41}$ In October, 1853, the Synod of Mississippi disapproved of the action of the Assembly of 1853 and agreed that the peace and harmony of the church demanded that the agitation over slavery cease. It "hailed with gratification" the creation of the Southern Aid Society as a "demonstration of fraternal feeling." Its aid was welcome, as the Synod's field was large, and it needed greatly both men and means to occupy it. ${ }^{42}$

The New School church in the South was ready for new developments, either in the form of a church-extension board in the Presbyterian Church or a new voluntary organization which would let slavery alone. The Presbytery of Hanover (Virginia) served notice on the North that it would not respond to the queries from the Assembly for information about slavery. ${ }^{43}$ The Presbytery of Winchester (Virginia) sent a circular letter to all northern New School presbyteries, warning that the southern church must have some reasonable assur-

34. Southern Aid Society: Its Constitution and Address, op. cit., 23.

35. Presbyterian Herald, November 10, 1853.

36. Oberlin Evangelist, XI, No. 24 (November 22, 1854), 190.

37. New York Daily Tribune, July 15, 1854.

38. Southern Aid Society: Its Constitution and Address, op. cit., 24.

39. Ibid., 4.

40. New Yor7 Observer, May 31, 1855. See "General Assembly Debate." C. P. Wing to Secretary, Huntsville, Alabama, June 7, 1847; C. P. Wing to Milton Badger, Huntsville, Alabama, September 17, 1847; Charles Hall to C. P. Wing, October 4, 1847, No. 850, Letter Book, 1847-1848, Volume U; C. P. Wing to Milton Badger, Huntsville, Alabama, October 18, 28, 1847, AHMS Correspondence.

41. First Annual Report of the Southern Aid Society (New York: D. Fanshaw, 1854), 18.

42. New Yor7c Observer, December 8, 1853. American Missionary (January, 1854), 22.

43. New York Observer, December 15, 1853. 
ance that the crusade against her would cease, or the church would be broken up. ${ }^{44}$

The New School churches in Tennessee did not limit themselves to threats in 1853. After the Murfreesboro Convention, the Synod of Tennessee resolved that her presbyteries would hold themselves ready to respond to any state of things which might open to them a wider field of domestic missions than they filled with the American Home Missionary Society. The Synod, however, disclaimed any desire to disturb the cooperation with the AHMS. ${ }^{45}$ When the Presbytery of Richland held its next meeting, it followed the suggestion of the Synod by authorizing its domestic mission agent to correspond with the general agent of the Southern Aid Society and secure whatever means could be obtained from that source to enable the feeble churches to sustain the gospel. ${ }^{46}$ Thus the groundwork was completed at the local level for the establishment of a conservative national society.

Outside the South, the rise of the Southern Aid Society served as an excuse among liberals, especially in the West, for a complete break of the AHMS with the South. It was claimed that there was now an organization to take care of that region and that the executive committee of the AHMS should turn its attention to other areas. ${ }^{47}$ In New England, except among the conservatives, the existence of the Southern Aid Society placed the AHMS in a position where it was looked on more favorably. In the summer of 1854, the Southern Aid Society's general agent was permitted to present his case before the General Association of Connecticut. After the meeting had heard the agent, resolutions were passed expressing a willingness to cooperate with all efforts to extend the gospel that were considered wise and practical. The General Association of Connecticut proceeded to pass measures in sympathy with the course of the AHMS, which excited much interest among the antislavery Christians in that region. S. S. Jocelyn, home secretary of the AMA in New York, inquired of Milton Badger if measures had been adopted by the AHMS executive committee in accord with the resolutions of the Connecticut declaration that the American Home Missionary Society was "correct in its position not to grant aid to slaveholding churches." In the absence of Badger, D. B. Coe, associate secretary, answered the communication. He stated that the position of the Society was precisely identical with the measures adopted by the General Association of Connecticut. "It is due to you, however," Coe added, "to state that according to my recollection, the resolution is not correctly quoted in your note." The quotation by Jocelyn was, however, identical with that which was contained in the record of the scribe of the General Association and the resolution printed in the minutes of the General Association of Connecticut. This was not the position taken at the time by the AHMS, as it then had many slaveholding churches that it aided. ${ }^{48}$

The Southern Aid Society address declared that most of the members of

44. Presbytery Reporter, IV, No. 4 (November 1, 1853), 99-100.

45. Christian Observer, October 22, 1853.

46. Presbyterian Witness, May 17, 1854.

47. Flavel Bascom to Milton Badger, Galesburg, Illinois, March 9, 1854, Letter No. 2308, Letter Book, 1857, Volume III, AHMS Correspondence.

48. S. S. Jocelyn to Milton Badger, July 31, 1854, No. 81768, AMA Correspondence. S. \$. Jocelyn to Milton Badger, New York, August 1, 1854; D. B. Coe to S. S. Jocelyn, New York, August 3, 1854, No. 81781, Letter Book, 1854, AHMS Correspondence. Austin Putnam (Scribe) to S. S. Jocelyn, Whitneyville, Connecticut, August 5, 1854, No. 5714, AMA Correspondence. Minutes of the General Association of Connectiout (New Haven: The Assoeiation, June, 1854), 10-11. 
the Society were supporters of the American Home Missionary Society. Some of them were "among its largest contributors." The public was informed that they still expected to aid the old Society. ${ }^{49}$ The Presbyterian Magasine observed that the Society was under the influence of the New School Presbyterians, "judging from its officers." 50 Out of fifty clergymen in attendance at the organizational meeting of the Southern Aid Society, thirty-two were from the North, including twenty New School men, five Congregationalists, three Old School Presbyterians and two Dutch Reformed clergymen. The conservative officers-vice presidents and directors-of the AHMS were opposed to the new developments at Albany and the statement of policy of the AHMS in the March number of the Home Missionary as well as the collection of information on slavery from the missionaries in the South. Fourteen of the AHMS officers were present at the opening meeting of the Southern Aid Society, and eleven became officers of the new Society. ${ }^{51}$ Two others, Charles Butler and Joseph Corning, both members of the executive committee of the AHMS, were life members of the Southern Aid Society. ${ }^{52}$ All sixteen were from the East. Three of them had led the debate against the General Assembly measures of 1853 . Henry A. Rowland and Ansel D. Eddy had introduced resolutions to postpone the report which requested information from the South in order to substitute milder measures. When the Assembly adopted the report, two protests were placed before the meeting by Henry A. Rowland and Samuel Cox respectively. Two protests were signed by twentynine commissioners to the Assembly, including Samuel C. Aiken from the Western Reserve, the only person present at the organizational meeting of the Southern Aid Society who lived west of the Appalachian Mountains. ${ }^{63}$

Henry A. Rowland, who took the lead on the conservative side of the debate in the Assembly of 1853, was pastor of the Presbyterian Church, Honesdale, Pennsylvania. He was born in Windsor, Connecticut, and educated at Yale. His first church was in Fayetteville, North Carolina, where he remained for three years. ${ }^{54}$ In the Assembly of 1846 , Rowland had informed his colleagues that slavery was recognized in the Bible in the same way that the parental government was recognized. ${ }^{55}$ After the Assembly of 1853 adopted the measures requesting information on slavery from the southern churches, Rowland published a pamphlet on the subject which denied that the Assembly had any constitutional authority to take such action. He assured his readers that the northern churches were no more responsible for the continuance of slavery than they were for that of the despotism of the Russian czar. It was his opinion that fellowship with one in great error did not imply sanction of that error. ${ }^{56}$

49. Journal of Commerce, November 1, 1853.

50. Presbyterian Magazine, cited by Independent (New York), December 1, 1853.

51. These included William Adams, Joel Parker, Anson G. Phelps, Samuel H. Cox, Thomas H. Skinner, Christopher R. Roberst-all Presbyterians of New York; Thomas Brainerd, Henry Rowland, Ambrose White and William Jessup-all Presbyterians of Pennsylvania; and Ansel D. Eddy, a New Jersey Presbyterian; William T. Dwight, Maine, Nathaniel W. Taylor, Connecticut, and Aristarchus Champion, New York-who were Congregationalists. Champion was in the process of moving from the Presbyterian to the Congregational Church. See Southern Aid Society: Constitution and Address, op. cit., 4-5.

52. Fourth Annual Report: Southern Aid Society (New York: George F. Nesbitt, 1857), 43.

53. Minutes, General Assembly, (1853), 327, 332, 334-335, 338.

54. New York Observer, September 8, 1859.

55. Christian Observer, June 12, 1846. New York Observer, June 13, 1846.

56. Henry A. Rowland, The Church and Slavery: Or the Relations of the Churches to Slavery Under the Constitution (New York: M. W. Dodd, 1854), 20, 41, 44. 
Ansel D. Eddy was born in New England in Williamstown, Massachusetts, and was trained in theology at Andover. He also began his ministry in the South, but was not installed as a pastor until he took over a Congregational church in New York within the bounds of the Presbytery of Geneva. Eddy spent twenty years as pastor of the Park Presbyterian Church in Newark, New Jersey. When he left this church, he was replaced by Rowland. ${ }^{57}$ In the Assembly of 1853, he took the lead in calling for "repose from ... agitation." "58 Eddy was a strong advocate of the American Colonization Society. In a speech before the Colonization Society in 1847 , he said that merely giving national freedom to slaves would not elevate them, nor would they be lifted out of degradation by being given religion and left in their present state. The answer seemed to be colonization. In 1854, he journeyed to New Haven, Connecticut, to attend the annual meeting of the Connecticut Colonization Society, where he made one of the leading speeches. $\mathrm{He}$ optimistically predicted that slavery would soon come to an end as a result of colonization. ${ }^{59}$ After the fortunes of Stephen A. Douglas were shaken in northern Illinois by the Kansas-Nebraska Act, Eddy was persuaded by Douglas to come to Chicago to take over a New School church. Douglas contributed liberally to Eddy's support, and the pastor defended the senator's position so firmly that those who were of antislavery sympathies represented him as a proslavery Douglas man. ${ }^{80}$

Samuel Cox, the third leader of the conservative triumvirate in the Assembly of 1853, was born in New Jersey of Quaker parents. He had started his career as an antislavery advocate and turned conservative in the late $1830 \mathrm{~s}$. $\mathrm{He}$ liked to remind his audience that there was no slavery as evil as the slavery of the soul. Cox became one of the most popular speakers at the Southern Aid anniversaries. In the Assembly of 1847, Cox expressed the belief that the doctrine that the master-slave relationship was essentially sinful was essentially foolishness. $^{61}$ In the Assembly of 1853 , he represented himself as being the friend of the black man, but held it as a conviction that ecclesiastical bodies had nothing to do "with the laws of Caesar. . ." "Christ so taught," Cox explained. ${ }^{62}$ When he was invited to accept a seat on the board of directors of the Southern Aid Society, he accepted and added: "We go for our whole country . . ." If the AHMS could not occupy the whole country, Cox was in favor of having a new institution occupy the neglected field. ${ }^{63}$ At the first anniversary meeting of the Southern Aid Society, he was critical of the established benevolent institutions because too much malignity was manifested against the South. ${ }^{64}$ "The worst slaveholder in the universe is the devil; the worst slaves in the world are the slaves of sin," he reminded his conservative colleagues again. ${ }^{65}$ What has the South done "to be proscribed, and excommunicated from northern beneficence?"

57. New York Evangelist, February 18, 1875.

58. New York Observer, June 9, 1853.

59. Thirtieth Annual Report, American Colonization Society, 1847, 31. Newark Daily Advertiser, August 4, 1854.

60. A. D. Eddy to Stephen A. Douglas, December 29, 1856, Stephen A. Douglas Papers (Manuseript: University of Chicago).

61. New York Observer, June 5, 1847.

62. Tbid., June 9, 1853.

63. Samuel H. Cox to Joseph Stiles, Brooklyn, New York, December 1, 1853, Southern Aid Society: Its Constitution and Address, op. cit., 19.

64. New York Observer, November 2, 1854.

65. The First Report of the Southern Aid Society (New York: D. Fanshaw, 1854), 55, 
he asked. ${ }^{66}$ Like most of his colleagues in the new organization, Cox was a life member of the American Colonization Society. ${ }^{67}$

Christopher R. Robert, who headed the mercantile firm of Robert and Williams, was the recording secretary of the AHMS and later its treasurer after Joseph Corning retired from that office. Robert was the only member of the Society's executive committee to become an officer of the Southern Aid Society. He served as a ruling elder of the Laight Street Presbyterian Church, and for nearly thirty years was superintendent of one of the largest Sunday schools in New York City. Before organizing his firm in New York, Robert operated a business in New Orleans. He was known for his benovolences, among which were the endowment of an Old Testament chair at Auburn Theological Seminary, aid to needy seminary students, and the establishment of the Lookout Mountain Educational Institution. Robert was a large contributor to the Colonization Society. ${ }^{68}$

Aristarchus Champion, a vice president of the American Colonization Society, was a merchant and land speculator of Rochester, New York. In 1856, he became President of the AHMS. This benevolent bachelor had the reputation of being one of the wealthiest men in the country. It was his custom to give a thousand dollars yearly to the benevolent organizations that he sustained. In 1854, when the American Tract Society came under attack because of slavery, he gave $\$ 1,500$ to purchase life memberships in the Tract Society for the missionaries in the AHMS. In 1854, he left the Presbyterian Church to take up membership in a new Congregational church. ${ }^{69}$

Many offices of the Southern Aid Society were held by the clergy and laymen who, while not officers of the AHMS, were important patrons of the organization. James Boorman, a life member of the AHMS and an active Presbyterian layman, was president of the Southern Aid Society. $\mathrm{He}$ was a member of the firm of Boorman, Johnson and Company, tobacco and iron merchants. For many years Boorman had been a vice president in the American Colonization Society. ${ }^{70}$ The treasurer of the Southern Aid Society was Gerard Hallock, the editor of the Journal of Commerce. Hallock was born in Massachusetts and remained an active Congregational layman throughout his life. The South Congregational Church in New Haven was built with money supplied by him. He was probably the most important individual involved in bringing the new society into existence. ${ }^{71}$ The New York Tribune spoke of the Southern Aid Society as

66. Ibid., 45 .

67. Thirty-Second Annual Report, American Colonization Society, 1849, 53.

68. National Cyolopaedia of American Biography, X, 492. John Q. Adams, A History of Auburn Theological Seminary (Auburn, New York: Auburn Seminary Press, 1918), 129.

69. National Cyclopaedia of American Biography, XIII, 592. Rochester Union and Advertiser, September 19, 20, 1871. Rochester Democrat and Chronicle, September 19, 1871. Franklin B. Dexter, Biographical Sketches of the Graduates of Yale College (New York: Henry Holt, 1885-1912), VI, 97. John A. Murray to Milton Badger, Geneva, New York, March 10, 1843, April 3, 1846, May 3, 1854; Áristarchus Champion to J. A. Murray, March 25, 1854; Champion to Charles Hall, Rochester, New York, January 29, 1849; Hall to Champion, February 19, 1949, No. 1638, Letter Book, 1848-1849, Volume 5, AHMS Correspondence; H. C. Bowen to Aristarchus Champion, July 10, 1855; Charles Seabody to Champion, January 23, 1855, Aristarehus Champion Papers (Manuseript: Rochester, New York, Public Library). See J. B. Richardson to A. Champion, Mareh 26, 1856, Champion Papers, for his benevolent contributions among the homes missionaries and the American Bible Society.

70. New York Times, January 26, 1866. Journal of Commerce, January 26, 1866. ThirtyFifth Report of the American Colonization Society, 1852, 54.

71. New York Times, January 5, 7, 1866. New York Tribune, January 5, 1866 . Journal of Commerce, January 6, 1866. 
the "pet of the Journal of Commerce." The Journal was the most outspoken newspaper in New York in opposition to the agitation of the sectional issues. During the Civil War the Journal was closed until Hallock's connection with it was ended. ${ }^{72}$ The general agent of the Southern Aid Society was Joseph C. Stiles, a New School clergyman who was born in Georgia and served churches in Kentucky and Virginia. Stiles was a former slaveholder. When Hallock had the South Congregational Church constructed in New Haven in 1852, Stiles was brought to serve as its pastor. When the War broke out, Stiles also became a supporter of the Confederacy. ${ }^{73}$

After the Southern Aid Society was organized in the Fall of 1853, because of the scarcity of money, no general appeal for funds was made, but a third anonymous donor came forward with a gift of a thousand dollars. ${ }^{74}$ In 1854, the executive committee of the new organization considered it the duty of the church, threatened with disruption, to endeavor to heal and bind together the union of the states. The Southern Aid Society was declared to be sectional in its operation, but national in its spirit. ${ }^{75}$ At the first annual meeting in 1854 , Oscar Newton, Presbyterian clergyman of Mississippi, addressed the Society and informed the audience that the political influence of the organization would be most beneficial. With attention focused on the political turmoil caused by the Kansas-Nebraska Act, the members agreed that "no violence of political anomosity, no abhorrence of the institutions of slavery, no imaginable combination of powerful objections, could possibly exonerate" them from the obligations to send the gospel to southern territories, had they never constituted a part of the nation; "therefore, the fact that the Southern states are ... an integral portion of our common country does not absolve us from this solemn duty."76

During the Southern Aid Society's annual meeting of 1854, Leonard Woods, professor at Andover Theological Seminary and vice president of the Society, addressed the members and said he had longed to persuade the North to cherish a spirit of Christian kindness toward the South. He had, many years ago, projected such a society, and therefore he hailed the formation with great interest and delight. ${ }^{77}$ George Grinnell, a director of the Society from Greenfield, Massachusetts, who had been president of the local auxiliary of the Colonization Society, organized in $1832,{ }^{78}$ wrote the convention that the more he reflected on the object of the new society and the motives for its establishment, the more important it seemed. When the president of the Society spoke in a similar vein, the New York Observer agreed by saying: "May not the good of the country and church be connected with the operations of this institution?"79 In an effort to broaden its source of funds during the following year, the Society pointed out

72. New York Tribune, October 31, 1854.

73. Gerard Hallock, History of the South Congregational Church, New Haven (New York: Tuttle, Morehouse and Taylor, 1865), 19, 44, 47. N. L. Rice, Lectures on Slavery Delivered in the North Presbyterian Church, Chicago (Chicago: Goodman and Cushing, 1860), 43. New York Observer, October 1, 1863. See New Haven Daily Register, June 2, 1856; New Haven Daily Palladium, May 31, June 9, 14, 1856, for controversy involving slavery and the South Church.

74. New Ÿork Observer, November 24, 1853. Journal of Commerce, Oetober 26, 1854.

75. Congregational Herald, November 16, 1854, eiting the New York Tribune.

76. American Missionary (December, 1854), 12. New York Observer, November 2, 1854, June 7, 1855. First Annual Report of the Southern Aid Society (New York: D. Fanshaw, 1854), 4.

77. Christian Observer, November 25, 1854.

78. The African Repository, VIII, No. 8 (October, 1832), 248.

79, New York Observer, November 23, 1854. 
in an address to the public that it was not motivated by prejudices, sectional or sectarian, but simply by the desire to secure a more equitable distribution of the immense home missionary power throughout all sections of the country. ${ }^{80}$

A Boston branch of the Southern Aid Society was organized in 1854, and sent out a circular letter announcing that it would make a call for funds in New England. In 1856, an anniversary meeting was held in Boston. Joel Parker, a leading conservative Presbyterian clergyman, addressed the friends of the Society. "Under God this Society has already done something to save the Union! When the salvation of the union can be promoted at the same time with the salvation of souls," he said, "what intelligent patriot can refuse to help forward a mission thus doubly blest?" Nehemiah Adams, a Congregational clergyman of Boston, rejoiced that the Southern Aid Society had softened sectional anomosities. $\mathrm{He}$ looked upon it as "the olive-branch brought by the dove, telling of the subsidence of the flood." The New York Tribune commented on Adams' speech. "We look upon the Doctor as the dove that brought it," said the editor. ${ }^{81}$

The Society sent out an "appeal" in 1857 which stated that the South welcomed the preaching of the entire word of God to bond and free. The Congregationalist of Boston agreed that no missionary of the Society had been molested, but claimed that there were hundreds of important passages in the Bible of which the organization's missionaries could not make an honest exposition and faithful application to the obvious spiritual needs of the people without securing their immediate martydom, or at least their expulsion from the South. The Christian Intelligencer of New York, organ of the Dutch Reformed Church, insisted, however, that the Society was doing a good work. The Christian Observer maintained its faith in the Southern Aid Society and added: "It is not only 'a good work' which the Society is doing-it is a great work." 82

John Todd, a Congregational clergyman of Pittsfield, Massachusetts, and a director of the Boston branch of the Southern Aid Society, spoke at the Boston auxiliary meeting in May, 1857. It was as absurd, he said, to withhold the gospel from the South because of slavery as it would be to stop the sale of manufactured goods to the South. ${ }^{83}$ George W. Bethune, a Dutch Reformed clergyman, spoke next and informed the audience that it was the duty of Christians to aid the South regardless of how much they hated slavery. He regarded the gospel as the only remedy for the evils of slavery just as it was the remedy of evils that were characteristic of the North. Bethune predicted that more and more the Southern Aid Society would carry along with it the reasonable and Christian people of the North. In reply to a statement made in the meeting that it was infidelity to refuse the gospel to the South because they were sinners, the editor of the New York Tribune observed that the gospel could only be preached to those who were willing to hear it. ${ }^{84}$

The national Society also held its anniversary in Boston in October, 1857, and Todd was again the principal speaker. He emphasized that the gospel provided the only mode of destroying evil and should be preached to all men. Talking, wrangling and voting had not solved the problem of slavery, said Todd.

\footnotetext{
80. New York Observer, November 2, 1854, June 7, 1855.

81. "Circular Letter of the Boston Branch, Southern Aid Society," Southern Aid Sooiety Constitution and Address (New York: Day Book, 1854).

82. Congregationalist, cited by Springfield Daily Republican, April 11, 1857. Christian Intelligencer and Christian Observer, cited by Presbyterian Witness, May 26, 1857.

83. Congregationalist, May 29, 1857.

84. Presbyterian Witness, June 16, 1857. New York Tribune, May 28, 1857.
} 
"I have no scorching sarcasm, no withering rebukes, no burning invective against the Home Missionary or any other society of like kind. . . . But I dare not say that the Gospel shall not be preached to every creature in this land," he added. ${ }^{85}$ In 1820, Todd had gone to Charleston, South Carolina, for his health and had been befriended and treated kindly by the people of the region. ${ }^{86}$ The Society report which was drawn up for 1857 pointed out that missionaries who went to the South to preach the sinfulness of the relation of master and slave and thus by their doctrine worked directly to destroy the foundations of society would surely meet a prompt and indignant rejection. But those who followed Jesus and his apostles and contented themselves with proclaiming the scriptural duties of the master and the servant were promised a warm reception. ${ }^{87}$ "Standing between the North and the South-passing down the missionary contributions of one, and bearing back the grateful acknowledgments of the other-like its Master, the Southern Aid Society is a Peace Maker," stated the report of the secretary of the Society, Joseph Stiles. ${ }^{88}$ This was the sentiment that prevailed at the meeting during this critical year when the New School Presbyterian Church was split over the issue of slavery, and the AHMS broke off its ties with the voluntary slaveholders of the South. A minister from Virginia testified that the Southern Aid Society "prolonged a spirit of true union between Christian men in the two sections of the country." 89 Stiles reported that the Synod of Mississippi had hailed the Southern Aid Society with gratitude and pride because it revealed that there were those who, although widely separated from them in sectional position, deeply sympathized with them in a common work. ${ }^{90}$

Thus the Southern Aid Society strove to occupy a position that was national in its stance at a time when all the institutions around it were becoming sectional. It was directed in this course, no doubt, by mixed motives. Few if any benevolent societies could match the Southern Aid Society membership in wealth and economic leadership. Of the twenty-nine Northern laymen who served as officers, at least seventeen could be included among the elite of commerce, banking and industry. Many of these had long-standing business ties with the South. Many were active political figures, including three who were ex-governors, and most of those who had held public office were lawyers by training and usually by practice. A large majority of the laymen were Whigs, but the Democrats were represented. There were, therefore, political ties that dated back to the rise of the second party system.

The twenty-six northern clerical representatives among the officers of the Southern Aid Society were also made up of the elite in ecclesiastical circles. They were ministers to the wealthiest urban churches and the officers of numerous other conservative benevolent societies. Twenty-three of the twenty-six were doctors of divinity. The remaining three were youthful members of the calling. They moved in the most conservative circles of society.

Individually the officers of the Society had many personal ties with the

85. New York Tribune, October 31, 1857.

86. John E. Todd, John Todd: The Story of His Life Told Mainly by Himself (New York: Harper and Brothers, 1876), 88-90. Springfield Republican, March 24, 1860. New York Tribune, May 28, 1857.

87. Fourth Annual Report of the Southern Aid Society, 1857 (New York: George F. Nesbitt, 1857), 11.

88. New York Observer, November 5, 1857.

89. Ibid.

90. Ibid. 
South. Whig and Democratic party connections were maintained with southern party leaders. Merchants, industrialists and bankers did extensive business in the South. In the period after the War of 1812, many merchants had operated businesses in the South at Charleston, New Orleans and Savanah. Many of the clergy, early in their careers, had served as missionaries or pastors in the more aristocratic sections of the South. Twelve northern officers had lived in the South, seven had been born there, and five had relatives living in the lower South. The Southern Aid Society was probably not speaking of a few isolated letters and comments of thanks when it recorded in the Report of 1857 that "many a Northern family has been laid under lasting obligation by the attention of the Society's agents to their wretched and friendless relatives in the far South." 91

The Society was made up of men who, with a few exceptions, had followed a life-long tradition of conservatism. The close ties between the conservative American Colonization Society and the Southern Aid Society can be seen by the fact that fifteen of the officers of the Southern Aid Society were also officers of the American Colonization Society, and thirty-six sustained the Colonization Society to the extent that they were life directors, life members or officers. The close connection between the two societies can be confirmed by the presence, at the organizational meeting of the Southern Aid Society, of R. R. Gurley and William McLain, general agent and secretary of the American Colonization Society. James C. Dunn, who was the official printer of the American Colonization Society during the $1830 \mathrm{~s}$, became one of the directors of the Boston branch of the Southern Aid Society. ${ }^{92}$

After the Southern Aid Society was firmly established, the increased friction between the northern and southern judicatories of the New School Presbyterian Church caused the home missionary committees of the synods of the upper south to become much more independent in their dealings with the AHMS. The committees expressed a willingness to work with the AHMS provided the Society's rules on slavery were not enforced on them too severely, and if part of the funds collected could go to Presbyterian church-extension. ${ }^{93}$ The executive committee could not yield on the last point any more than it could compromise on the first. The Congregational associations were firmly opposed to the Presbyterian church-extension program. They suspected that Presbyterian funds would go into a church building program and that Congregational benevolence would be used to supply a ministry to the Presbyterian churches. Unlike the slavery question, on church extension the moderate and many conservative Congregationalists were united with their radical colleagues.

As political and sectional hostility mounted, the synods of Tennessee and Missouri fell under the control of the opponents of the AHMS, and the missionary committees in each moved toward independence. The secretaries of the American Home Missionary Society challenged the policy of dividing their domestic missions funds between the AHMS and the Church Extension Committee by cutting off additional aid until they agreed to commit all of their funds to

91. New York Tribune, October 31, 1857.

92. Thirty-Third Annual Report, 1850, 11, 25; Thirty-Sixth Annual Report, 1853, 3, 58; Thirty-Eighth Annual Report, 1855, 13, American Colonization Society. Southern Aid Society: Its Constitution and Address, op. cit., 4.

93. James MeChain and Samuel Sawyer to Milton Badger, Abingdon, Virginia, June 24, 1856; R. P. Wells to Secretary, Jonesboro, Tennessee, July 8, 1856, AHMS Correspondence. 
the treasury of the AHMS. ${ }^{94}$ The situation in the Synod of Tennessee was complicated for a time when Andrew Blackburn, one of the editors of the Presbyterian Witness of Knoxville, Tennessee, volunteered himself as the Synod home missionary agent. He was the owner of a slave, a critic of the AHMS and an advocate of the Presbyterian church-extension organization. ${ }^{95}$

In the Synod of West Tennessee, where slavery existed on a large scale, the domestic missionary committee appeared less independent. The Synod appealed to the American Home Missionary Society for aid. The domestic missions secretary wrote that the committee could not believe that "simply because the 'field already ripe for the harvest' lies in the sunny North" the "region of domestic servitude which called for aid would not be heard." ${ }^{96}$ Apparently the call was not heard.

In the lower South the New School leaders were making efforts to pull the presbyteries of eastern Tennessee and southwestern Virginia away from the American Home Missionary Society. Oscar Newton of Jackson, Mississippi, urged, through the columns of the Presbyterian Witness, that the Presbyterians should leave the AHMS in preference for the Southern Aid Society. Frederick Ross, a powerful figure among the New School Presbyterians of the upper Tennessee Valley, exerted his influence through private correspondence. ${ }^{97}$ Voluntary agents of the Southern Aid Society were competing for funds that had normally gone to the American Home Missionary Society agents in Kentucky, Missouri, Tennessee and Virginia. Many of the destitute areas looked upon the Southern Aid Society as a means of supplementing the funds secured from the AHMS, but Badger and Coe, the secretaries, objected to this arrangement in the name of the executive committee. ${ }^{98}$

At the national level the AHMS moved more cautiously against the Southern Aid Society. When the Southern Aid Society was organized in 1853, eleven of its officers were also officers of the AHMS, twenty-one others were life directors and five were life members. A total of thirty-seven had sustained the American Home Missionary Society to the extent that they were life directors, life members, or officers. Since so many of the AHMS officers and supporters were deeply committed to the Southern Aid Society, the secretaries hesitated to oppose it openly. In January, 1854, however, Badger privately warned an AHMS agent to advise against unqualified endorsement of the Southern Aid Society.99

94. Samuel Sawyer and James MeChain to Secretaries, Abingdon, Virginia June 24, 1856; W. E. Caldwell to Secretary, Cleveland, Tennessee, June 15, 1856; D. B. Coe to Samuel Sawyer, Oetober 31, 1855, No. 1297, Letter Book, 1855-1856, Volume I; Samuel Sawyer to D. B. Coe, Rogersville, Tennessee, Oetober 19, 1855; Timothy Hill to Milton Badger, Breman, Missouri, May 14, 1856; Hill to Coe, Breman, Missouri, September 16, 1856; Hill to Coe, Breman, Missouri, February 5, 1857; Coe to Hill February 26, 1857, Letter No. 2232, Letter Book, 1856-1857, Volume II, AHMS Correspondence.

95. J. J. Robinson to David Coe, Maryville, Tennessee, January 20, 1855; John N. Blackburn to Secretary, Benton, Tennessee, August 27, 1856; Samuel Sawyer to David Coe, Rogersville, Tennessee, July 23, 1856, AHMS Correspondence.

96. Robert Callwell to Secretary, Pulaski, Tennessee, April 9, 1855, AHMS Correspondence.

97. Samuel Sawyer to Milton Badger, Rogersville, Tennessee, March 30, 1855, AHMS Correspondence.

98. Benjamin Mills to David Coe, Frankfort, Kentucky, May 21, 1857; J. J. Robinson to David Coe, Marysville, Tennessee, January 20, 1855 ; A. H. H. Boyd to Secretary, Winchester, Virginia, September 25, 1855 ; Milton Badger to A. H. H. Boyd, October 6, 1855, Letter No. 1086, Letter Book, 1855-1856, Volume I; Timothy Hill to David Coe, St. Louis, February 5, 1857, AHMS Correspondence.

99. Milton Badger to B. P. Stone, January 31, 1854, No. 2051, Letter Book, 1853-54, Volume II, AHMS Correspondence. 
But the American Home Missionary Society saw fit to maintain a studied silence and to withhold public statements concerning the Southern Aid Society. A clash of the two viewpoints in the ranks of the AHMS seemed imminent, but the march of events prevented the Southern Aid Society from becoming an effective competitor in domestic missions. The existence of the Southern Aid Society served as an excuse for the moderates in the AHMS to stand with the radicals in demanding that the executive committee of the American Home Missionary Society deny aid to southern churches that were involved in the system of human bondage. ${ }^{100}$ The slaveholding churches now had their peculiar domestic missionary society. Under the pressure created by the election of 1856 , the executive committee of the AHMS adopted a new rule on December 22, 1856, denying aid to churches which contained slaveholding members unless it could be proven that the relationship was sustained for the benefit of the servant. ${ }^{101} \mathrm{With}$ the acceleration of events, before falling leaves announced the coming of another winter, the AHMS had withdrawn all aid from the slaveholding states, and the southern Presbyterian churches had seceded from the New School General Assembly. ${ }^{102}$ With the quickening pace of political developments, the coming of the Civil War made the dispute over home missionary aid a pointless question, but the sectional dispute concerning domestic missions contributed to the cleavage in society and made a political division more difficult to prevent.

100. Flaval Bascom to Milton Badger, Galesburg, Illinois, March 9, 1854, Letter No. 2308, Letter Book, 1857, AHMS Correspondence.

101. Congregational Herald, January 29, 1857. D. B. Coe to Lewis Tappan, February 6, 1857, No. 2042, Letter Book, 1856-1857, Volume II, AHMS Correspondence.

102. General Assembly Minutes, Presbyterian Church (New School), 1857, 403-406. Presbyterian Quarterly Review, VI, No. 22, (Beptember, 1857), 246. 